\title{
Characterization of Biomolecules with Antibiotic Activity from Endophytic Fungi Phomopsis Species
}

\author{
Janko Ignjatović, ${ }^{1}$ Nevena Maljurić, ${ }^{1}$ Jelena Golubović, ${ }^{1}$ Matjaž Ravnikar, ${ }^{2}$ \\ Miloš Petković, ${ }^{3}$ Nika Savodnik, ${ }^{4}$ Borut Štrukelj ${ }^{2}$ and Biljana Otaševićc ${ }^{1, *}$ \\ ${ }^{1}$ Department of Drug Analysis, University of Belgrade, Faculty of Pharmacy, Vojvode Stepe 450, 11221 Belgrade, Serbia \\ ${ }^{2}$ Chair for Pharmaceutical Biology, Faculty of Pharmacy, University of Ljubljana, Aškerčeva cesta 7, 1000 Ljubljana, Slovenia \\ ${ }^{3}$ Department of Organic Chemistry, University of Belgrade - Faculty of Pharmacy, Vojvode Stepe 450, 11221 Belgrade, Serbia \\ ${ }^{4}$ Biotechnical Faculty, University of Ljubljana, Jamnikarjeva 101, 1000 Ljubljana, Slovenia \\ *Corresponding author: E-mail: biljana.otasevic@pharmacy.bg.ac.rs
}

Phone: +381 113951 334; Fax: +381 113972840

Received: 07-08-2019

\begin{abstract}
Recently, growing interest is devoted to investigation of bioactive secondary metabolites of endophytic fungi. Thus, as an extension to our previous achievements related to antimicrobial potential of endophytic fungi, Phomopsis species isolated from conifer needles was selected as appropriately promising natural source for drug discovery. Its dichloromethane and ethanol extracts considerably inhibited growth of Escherichia coli and Staphylococcus aureus. Moreover, the individual compounds of dichloromethane extract have been separated, collected and purified using semi preparative liquid chromatographic analysis and comprehensively characterized using mass spectrometry (MS) and nuclear magnetic resonance spectroscopy (NMR). Based on their antimicrobial activity and unique structural characteristics in comparison with well-established drugs from the same therapeutic category, two dominant compounds (Z)-(Z)-2-acetoxyprop-1en-1-yl-3-(3-((E)-3,4-dihydroxypent-1-en-1-yl)oxiran-2-yl)acrylate (denoted as 325-3) and (Z)-(Z)-2-acetoxyprop-1en-1-yl 3-(3-((E)-4-hydroxy-3-oxopent-1-en-1-yl)oxiran-2-yl)acrylate (denoted as 325-5) were recognized as valuable leading structures for future discovery of novel antibiotics.
\end{abstract}

Keywords: Endophytic fungi; antibacterial activity; HPLC; GC-MS; NMR

\section{Introduction}

During evolution, plants have developed certain defending capabilities such as producing specific secondary metabolites in order to repel microorganisms, insects, or other animals that are feeding on them. ${ }^{1}$ Moreover, plant tissues contain many types of microorganisms, which are referred to as endophytes. ${ }^{2-4}$ During certain period of their life, endophytes colonize living internal tissues of their plant hosts without causing any symptoms. ${ }^{2}$ Usually, an endophyte is specific for each host and is characteristic for conditions and geographical area in which its host develops. ${ }^{5,6}$ Endophytic organisms seem to have mutualistic relation to their plant host by means that they preserve hosts from threats of pathogenic microorganisms, insects or other animals in return for their nutrition. ${ }^{7,8}$ In order to facilitate the survival of a host plant, endophytes help host plant to overcome the invasion of pathogenic microorganisms by producing secondary metabolites. ${ }^{9}$ There is also evidence that endophytes produce metabolites for plant growth regulation, productivity and phytoremediation. ${ }^{10,11}$

The literature search pointed out significant antibacterial and antimycotic activity of endophytic fungi Phomopsis species. ${ }^{12-16}$ For example, secondary metabolites from fungus that was isolated from the leaves of tropical fruit tree Garcinia dulcis demonstrated activity on $\mathrm{Myco-}$ bacterium tuberculosis. ${ }^{17}$ Additionally, fungus isolated from marine-derived mangrove showed considerable potential for inhibition of Candida albicans and Fusarium oxysporum. ${ }^{18}$ It is concluded that the fungus is susceptible to production of wide variety of secondary metabolites 
and this fact is closely dependent on factors like type of plant host, plant organ, eventual cohabitance with other strains of microorganisms, climatic conditions, sessional fluctuations, habitat microclimate, temperature, etc. ${ }^{5,19-21}$ Rakshith et al. state that the genus Phomopsis has been known to be a rich source of bioactive secondary metabolites of novel, diverse structure and function such as Phomopscichalasin, cytochalasin, convolvulanic acid, and isobenzofuranones, oblongolide, phomopsolide, Phomodiol, Phomoxanthones, and Xanthones dimer, phomoenamide, phomonitroester, deacetylphomoxanthone $\mathrm{B}$, dicerandrol A, (1S,2S,4S)-p-menthane-1,2,4-triol, uridine, ethyl 2,4- dihydroxy-5,6-dimethylbenzoate and Phomopscilactone. ${ }^{22}$ Those structures have been further tested and showed antibacterial, antifungal and antialgal activity. ${ }^{23}$

Thus, the main aim of this study was investigation of endophyte Phomopsis species isolated from conifer needles in Slovenia and its secondary metabolites responsible for the antimicrobial effect on selected representatives of $\mathrm{G}^{-}$ (Escherichia coli) and $\mathrm{G}^{+}$(Staphylococcus aureus) bacteria.

\section{Experimental}

\section{1. Chemicals and Reagents}

For the purpose of executing microbiological tests, endophyte or bacterial sawing and endophyte extract preparation we have used: Potato dextrose agar - PDA, quality level 200, Sigma-Aldrich (Taufkirchen, Germany), LB broth, quality level 200, Sigma-Aldrich (Taufkirchen, Germany), Mueller-Hinton agar, quality level 100, Sigma-Aldrich (Taufkirchen, Germany), Dichloromethane, $\geq$ 99.0\% purity, Sigma-Aldrich (Taufkirchen, Germany), Ethanol, $\geq 99.9 \%$ purity, Sigma-Aldrich (Taufkirchen, Germany), Methanol, $\geq 99.9 \%$ purity, Sigma-Aldrich (Taufkirchen, Germany) and Ampicillin USP standard substance, 99.3\% purity, Sigma-Aldrich (Taufkirchen, Germany).

Furthermore, for the purpose of conducting all chromatographic analysis, GC-MS and NMR we have used: Acetonitrile, 99.99\% purity, Sigma-Aldrich (Taufkirchen, Germany), Formic acid solution in water. 0.1\% (v/v), Sigma-Aldrich (Taufkirchen, Germany), Helium gas, $99.999 \%$ purity, Sigma-Aldrich (Taufkirchen, Germany), Deuterochloroform, 99.9\% purity, Sigma-Aldrich (Taufkirchen, Germany), Tetramethylsilane as the internal standard, > 99.99\% purity, Sigma-Aldrich (Taufkirchen, Germany), DMSO, $\geq 99 \%$ purity, Sigma-Aldrich (Taufkirchen, Germany), Deuterochloroform, 99.9\% purity, Sigma-Aldrich (Taufkirchen, Germany).

\section{2. Preparation of Endophytic Material}

Endophytic fungi Phomopsis species, which is isolated from conifer needles, has been provided by the Department of Wood Science and Technology within Biotechni- cal Faculty, University in Ljubljana, Slovenia. Potato dextrose agar - PDA was used for fungal cultivation. PDA was prepared by dissolving $8.4 \mathrm{~g}$ of dry mixture in $200 \mathrm{~mL}$ of ultra-pure water, poured in Petri plates and left to solidify in sterile conditions. Afterwards, fungal sample was sawed on PDA plates and left to grow on room temperature (approximately $25^{\circ} \mathrm{C}$ ) for one month and then plate content was grinded and mixed using homogenizer Ultra Turrax (Ika, Staufen, Germany).

Two types of extraction solvents were tested. In accordance with previous literature records, dichloromethane and ethanol were selected due to their differences in polarity and ability to extract potential secondary metabolites. ${ }^{24}$ Therefore, homogenization of fungal material was followed with the addition of $50 \mathrm{~mL}$ of dichloromethane and absolute ethanol separately and thorough mixing. Moreover, the mixtures were ultrasonicated for 15 minutes covered with thin foil and then left overnight at room temperature for extraction process to take place. Then, the mixtures were filtered through filter paper and solvent was removed using rotavapor set at $50{ }^{\circ} \mathrm{C}$ while the pressure was 700 mbar. Moreover, dichloromethane solution evaporated fully out of extract under reduced pressure, while ethanol extract sample had to be additionally left overnight on room temperature so that the rest of ethanol and remaining water could evaporate freely. Afterwards, both dry extracts were weighed and dissolved in approximately $5 \mathrm{~mL}$ of mixture of methanol and ultra-pure water (50:50, $\mathrm{v} / \mathrm{v}$ ) so that concentration of both extracts was approximately $8 \mathrm{mg} / \mathrm{mL}$. This step was enhanced using ultrasonication for approximately 10 minutes. Afterwards, both samples were filtered through $0.22 \mu \mathrm{m}$ nylon membranes (Agilent Technologies, Santa Clara, USA).

\section{3. Microdilution Assay}

In order to determine antibiotic activity of prepared extracts from endophyte Phomopsis species that was isolated from conifer needles, cultures of Escherichia coli (strain DH5- $\alpha$ ) and Staphylococcus aureus (strain ACTC 10788) obtained from permanent cultures, were used. LB broth for bacterial cultivation was prepared by dissolving $8 \mathrm{~g}$ of dry mixture in $400 \mathrm{~mL}$ of ultra-pure water. Bacterial suspensions were then prepared in a way that $20 \mathrm{~mL}$ of $\mathrm{LB}$ medium was added to the centrifuge container after which E. coli or S. aureus were seeded separately from the permanent culture. The centrifuge container was left over night and shaked in an incubator at $37^{\circ} \mathrm{C}$ in order to multiply the bacteria.

Next, $2 \mathrm{mg}$ of dichloromethane and $2 \mathrm{mg}$ of ethanol dry extracts of the endophyte were dissolved separately in $1 \mathrm{~mL}$ of mixture of methanol and ultra-pure water (50:50, $\mathrm{v} / \mathrm{v}$ ) and used for initial antimicrobial activity testing within microdilution tests. Prior performing microdilution tests dissolved endophyte extract in mixture of methanol and ultra-pure water $(50: 50, \mathrm{v} / \mathrm{v})$ was additionally concen- 
trated using Speed Vac Plus (Savant, Waltham, MA, USA) to desired volume, required for microdilution assays.

Bacterial suspensions were diluted in LB broth in order to set the suitable optical density between 0.08 and 0.10 of the mixture by measuring the absorbance of a mixture at $\lambda=600 \mathrm{~nm} \cdot{ }^{25,26}$ Assay was carried out on a microwell plate by executing tests in duplicates for extract activity as well as for positive and negative control. Activity of extract was tested in a mixture of $90 \mu \mathrm{L}$ of E. coli or S. aureus suspension solution in LB broth and $10 \mu \mathrm{L}$ of extract obtained as described above. Negative control was prepared using $90 \mu \mathrm{L}$ of $E$. coli or $S$. aureus suspension solution in LB broth and $10 \mu \mathrm{L}$ of mixture of methanol and ultra-pure water $(50: 50, \mathrm{v} / \mathrm{v})$. As positive control, 90 $\mu \mathrm{L} E$. coli or $S$. aureus suspension solution in LB broth was mixed with $1 \mu \mathrm{L}$ of $100 \mathrm{mg} / \mathrm{mL}$ solution of ampicillin that was dissolved in $9 \mu \mathrm{L}$ of $50 \%(\mathrm{v} / \mathrm{v})$ solution of methanol in water. Plates were analysed instantly at absorbance of 600 $\mathrm{nm}$ and left overnight under incubation temperature of $37^{\circ} \mathrm{C}$ for growing and to be measured also the next day in order to detect any changes in the bacterial growth. Changes in absorbance due to bacterial growth were used to calculate bacterial inhibition rate for each of the Phomopsis species extract types. The microdilution assay for determination of antibacterial activity was done for every prepared sample in duplicate and average result was calculated.

\section{4. Isolation and Chemical Structure Characterization of Components from Endophytic Fungal Material}

Prior chromatographic and spectral analysis, $2 \mathrm{mg}$ of dichloromethane dry endophyte extract was dissolved in 1 $\mathrm{mL}$ of methanol and ultra-pure water $(50: 50, \mathrm{v} / \mathrm{v})$. Isolation and collection of components from endophyte extract was performed on Dionex Ultimate 3000 HPLC system (Thermo Fisher Scientific, Dreieich, Germany) equipped with DAD detector and binary pump. Separation was achieved on Hypersil Gold semi-preparative revered-phase HPLC column (C18, particle size $5 \mu \mathrm{m}$, length $150 \mathrm{~mm}$, internal diameter $10 \mathrm{~mm}$, Thermo Fisher Scientific, Dreieich, Germany) at $25^{\circ} \mathrm{C}$. Samples were maintained at $10{ }^{\circ} \mathrm{C}$ in autosampler prior analysis. Injection volume was $100 \mu \mathrm{L}$. A gradient elution program was composed of acetonitrile as mobile phase A and $0.1 \%(\mathrm{v} / \mathrm{v})$ formic acid solution in water as mobile phase $\mathrm{B}$. The gradient program started with $95 \%(\mathrm{v} / \mathrm{v})$ mobile phase B. During 28 minutes, the percentage of mobile phase B was decreasing to $5 \%(\mathrm{v} / \mathrm{v})$, following the return to the initial ratio in 0.05 minute. Column was then re-equilibrated, so the total run time was 40 minutes at a flow rate of $2 \mathrm{~mL} / \mathrm{min}$. Detection was performed simultaneously, by measuring the absorbance at $220 \mathrm{~nm}, 235 \mathrm{~nm}, 254 \mathrm{~nm}$ and $285 \mathrm{~nm}$ wavelength in order to assure recording of all possible components with different spectral properties.
Fraction collection procedure was performed on Phomopsis species dichloromethane dry extract dissolved in $50 \%(\mathrm{v} / \mathrm{v})$ solution of methanol in water, using the aforementioned chromatographic method on Dionex Ultimate 3000 HPLC system with DAD detection. Five distinct peaks from the chromatogram at the retention times of approximately $12.88,13.67,14.40,16.02$ and $17.13 \mathrm{~min}$ have been manually collected in Eppendorf tubes. Solvent from separate peak fractions was removed using rotavapor set at $50{ }^{\circ} \mathrm{C}$ while the pressure was $700 \mathrm{mbar}$ and dry peak residues have been used for further analytics.

Mass spectrometry (MS) analyses were done on Agilent Technologies 5975C MS system (Agilent Technologies, Santa Clara, USA) coupled with Agilent Technologies 6890N GC system (Agilent Technologies, Santa Clara, USA). Initial temperature of the oven of the GC system was $60^{\circ} \mathrm{C}$ and maximum temperature was $325^{\circ} \mathrm{C}$. Front inlet of the system was set in mode to split ratio 10:1, while initial temperature was set at $200^{\circ} \mathrm{C}$, pressure was $14.47 \mathrm{psi}$ and split flow was $10.0 \mathrm{~mL} / \mathrm{min}$. The method used Agilent Technologies HP-5 5\% Phenyl Methyl Siloxane, Agilent 19091J-433 column, (internal diameter $0.25 \mathrm{~mm}$, length $30.0 \mathrm{~m}$, film thickness $0.25 \mathrm{~mm}$, column format 7 inch, manufacturer Agilent Technolog Santa Clara, USA) and helium gas pumped at $1 \mathrm{~mL} / \mathrm{min}$ flow rate. The fractions collected using semi-preparative HPLC analysis with the concentration of $0.1 \mathrm{mg} / \mathrm{mL}$ were introduced into GC-MS system with $1 \mu \mathrm{L}$ injection volume and total run time was 44 minutes. The mode of ionization was electron impact operated at $70 \mathrm{eV}$. Low mass scan parameters for MS was 10, while high mass scan parameter was 550.

For acquiring nuclear magnetic resonance (NMR) spectra on Bruker Ascend $400(400 \mathrm{MHz})$ spectrometer (Billerica, MA, USA), the fractions collected using semi-preparative HPLC analysis, were evaporated using Rotavapor R-114 (Büchi, Flawil, Switzerland) and dry content weighing about $5 \mathrm{mg}$ was dissolved in $250 \mu \mathrm{L}$ deuterochloroform. NMR spectra were recorded at $25^{\circ} \mathrm{C}$ and chemical shifts were given in parts per million $(\delta)$ downfield from tetramethylsilane as the internal standard.

\section{5. Disc Diffusion Method for Determining the Antibiotic Potential}

Firstly, the microbial cultures of E. coli and S. Aureus were diluted with saline solution until the density of 0.5 McFarland. Both cultures were seeded on separate Mueller-Hinton agar plates. Afterwards, $15 \mu \mathrm{L}$ of collected peak fraction 3, 4 and 5 were added on separate places on seeded Mueller-Hinton agar plates, while $15 \mu \mathrm{L}$ DMSO served as control on each plate. Then, plates were incubated in thermostat at $37^{\circ} \mathrm{C}$ in the period from 16 to $24 \mathrm{~h}$. Growth inhibition zone diameter readings are performed after incubation for each of the peak fractions. 


\section{Results and Discussion}

\section{1. Evaluation of Endophytic Fungi Extract Antibiotic Activity}

Within microdilution assay for antibiotic activity of dichloromethane extract against E. coli after $24 \mathrm{~h}$, average absorbance value 0.4603 was for the negative control, and 0.1590 for the positive control. Dichloromethane extract of Phomopsis species showed absorbance value of 0.2812 . Therefore, it was concluded that this extract demonstrated inhibition rate of $59.44 \%$. The same set of microdilution test experiments were repeated using dry ethanol extract of the fungi and these also pointed out the presence of antibacterial activity. Moreover, it was observed that ethanol extract demonstrated $51.63 \%$ of inhibition rate against $E$. coli.

In order to further evaluate the relationship between extract concentration and the level of antibiotic activity on E. coli, a microdilution experiment was repeated using additional four lower volumetric ratios of dichloromethane extract, since better inhibition dependency was observed comparing to ethanol extract of fungus. In this experiment also negative control was used in the same volumetric ratios. Therefore, Phomopsis species dichloromethane extract samples were prepared so that the percentage of Phomopsis species dichloromethane extract solution in LB broth suspension of $E$. coli was approximately $10 \%, 5 \%, 2.5 \%$ or $1 \%$ $(\mathrm{v} / \mathrm{v})$. From the results, the concentration dependent antibiotic activity was observed. In specific, average absorbance value of 0.2812 was measured for $10 \%(\mathrm{v} / \mathrm{v})$ extract, 0.3305 for $5 \%(\mathrm{v} / \mathrm{v})$ extract, 0.3275 for $2.5 \%(\mathrm{v} / \mathrm{v})$ extract and 0.3896 for $1 \%(\mathrm{v} / \mathrm{v})$ extract. As expected, lower presence of extract or control influenced greater growth of $E$. coli. Furthermore, even the sample with the lowest ratio of Phomopsis species dichloromethane extract also demonstrated antibiotic effect comparing to the negative control, as can be concluded from the average absorbance value for extract $(0.3896$ at $1 \%, v / v)$ comparing to the average absorbance value for negative control (0.4603). Based on presented data, inhibition concentration of dichloromethane extract that eradicates $50 \%$ of bacteria (IC50) was calculated to be $6.95 \%$.

Furthermore, the same procedure was performed once again for evaluation of antibacterial activity of endophytic fungi extracts against $S$. aureus after $24 \mathrm{~h}$. It was noticed that ethanol extract has high inhibition rate of $92.80 \%$ on the growth of $S$. aureus during preliminary tests. On the other side, dichloromethane extract did not show notable antibacterial activity against $S$. aureus. Thus, we continued with microdilution assay with Phomopsis species ethanol extract. Samples for microdilution test were prepared so that Phomopsis species ethanol extract concentration in $S$. aureus final suspension was approximately $10 \%, 5 \%$ and $1 \%(\mathrm{v} / \mathrm{v})$. From the results, the concentration dependent antibiotic activity was observed. In specific, average absorbance value of 0.1755 was measured for $10 \%(\mathrm{v} / \mathrm{v})$ extract, 0.1805 for $5 \%(\mathrm{v} / \mathrm{v})$ extract and 0.2010 for $1 \%(\mathrm{v} / \mathrm{v})$ extract.
Absorbance result for negative control was 0.4655 and for positive control 0.1530. Moreover, even sample with lowest tested dilution of $1 \%(\mathrm{v} / \mathrm{v})$ of Phomopsis species ethanol extract has pronounced antibiotic activity comparing to both positive and negative control. Out of available data, IC50 value of Phomopsis species ethanol extract for S. aureus of $1.30 \%$ was calculated.

This data supported the hypothesis that biomolecules from investigated endophytic fungi have the potential to become candidates for new potential drugs as demonstrated bioactivity could represent valuable contribution to current antibacterial therapy with a proper chance for dealing with growing trend of bacterial resistance. Based on presented data and having in mind future industrial exploitation of prepared extracts, we have further analysed the components of Phomopsis species dichloromethane extract using spectral and chromatographic tools, due to its stability and facilitated dry extract preparation comparing to the ethanol one. Furthermore, based on the previous research of the group ${ }^{24}$ we expected that more potent secondary metabolites could be extracted from the fungal material using dichloromethane as extraction solvent.

Nevertheless, Phomopsis species dry ethanol extract secondary metabolites could be a subject for further analytical research using proposed methods in this article, that were developed for characterization of components of Phomopsis species dichloromethane extract.

\section{2. Active Biomolecules Isolation and Chemical Structure Elucidation}

Dichloromethane dry extract dissolved in $50 \%(\mathrm{v} / \mathrm{v})$ solution of methanol in water has been further analysed using semi-preparative HPLC method. Total number of five peaks was inspected in the chromatogram at the retention times of $12.88,13.67,14.40,16.02$ and $17.13 \mathrm{~min}$, respectively (Figure 1). The compounds related to all five peaks seemed to have relatively similar spectral properties (Figure 2), so it was possible to record all of them in a single chromatogram acquired at $235 \mathrm{~nm}$ detection wavelength. As expected, due to differences in chromatographic systems (e.g. the composition of mobile phase and chemistry of stationary phase, technical characteristics of used instruments) employed during sample collection and following GC-MS analysis, the previously reported retention times were different from those in recorded total ion chromatogram (Figure 3 and 8). Despite this, reliable peak-to-peak tracking was accomplished with the same elution order and all relative retention times preserved. Although there was a risk that the first two eluting peaks belong to compounds with activity that was measured for the whole extract, we deliberately omitted them in further work by means of preparative chromatography and fraction collections for chemical structure elucidation. Authors have invested effort to chromatographically resolve 
all peaks for further processing. However, the purity of fractions was serious limitation as well as concentration level of a compound in a collected fraction. Due to this, background noise was too high and we could not perform accurate data analysis except for last three eluting peaks.

In line with fraction collection, we have performed disc diffusion method for determining the antibiotic potential of fractions as verification of bioactivity in order to ensure that ascribed bioactivity of whole extract could be related to all collected fractions. Tested concentration of peak fraction 3 and 4 was $1 \mathrm{mg} / \mathrm{mL}$, while fraction of peak 5 had the concentration $3 \mathrm{mg} / \mathrm{mL}$. The results revealed that there was no activity on any of the microorganisms tested for peak fraction 4 . For peak fraction 3, a $6 \mathrm{~mm}$ diameter inhibition zone was observed on $S$. aureus plate, while no antimicrobial activity was observed on E. coli plate. Furthermore, for peak fraction 5 , a $7 \mathrm{~mm}$ diameter of the inhibition zone was observed against $S$. aureus and $4 \mathrm{~mm}$ diameter of the inhibition zone was noted on $E$. coli plate. The test pointed out that only peaks with elution order 3

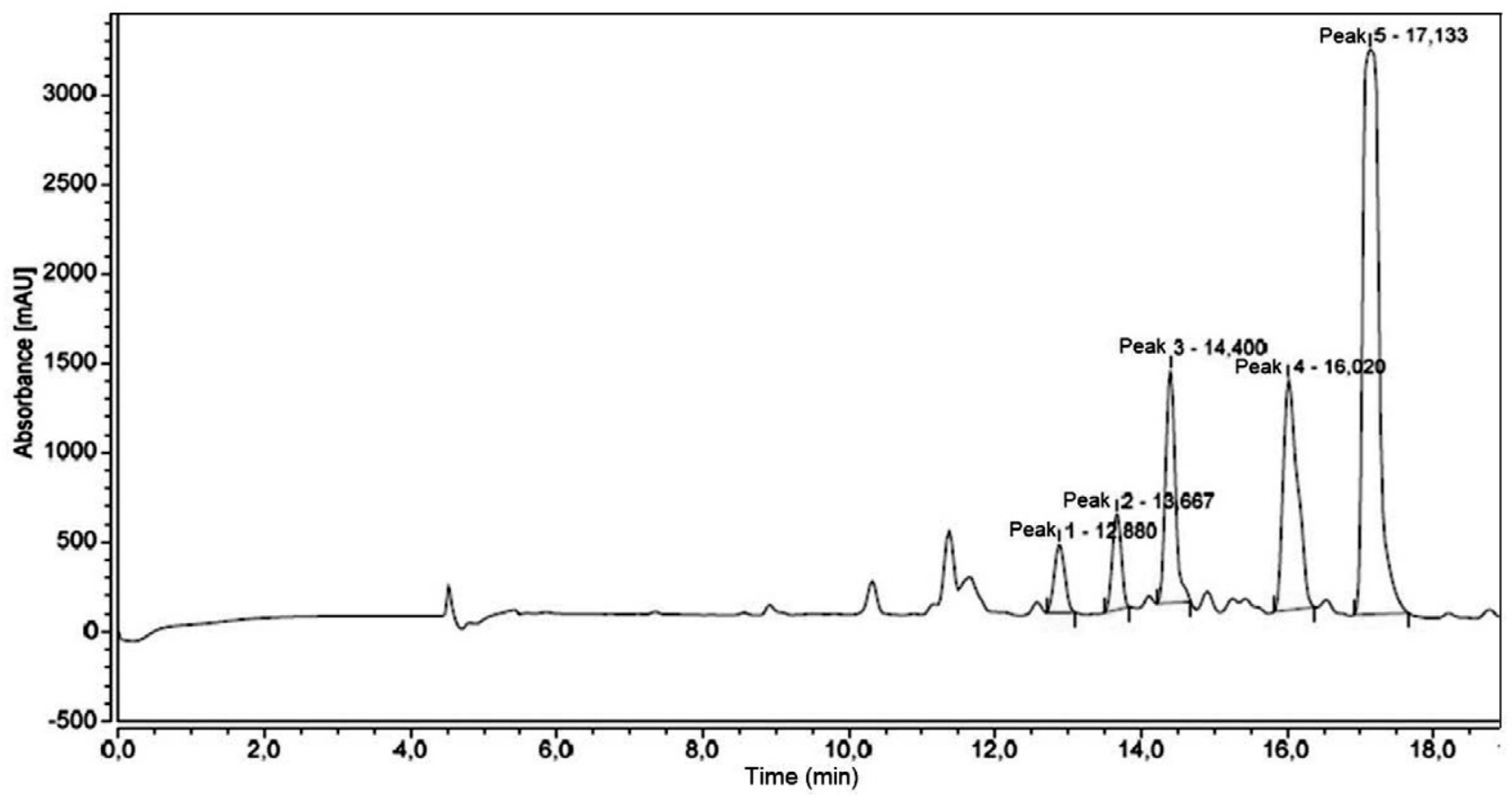

Figure 1. Chromatogram of Phomopsis species dichloromethane dry extract dissolved in mixture of methanol and water 50:50 (v/v) from semi-preparative HPLC analysis

Table 1. ${ }^{1} \mathrm{H}(400 \mathrm{MHz})$ and ${ }^{13} \mathrm{C}(100 \mathrm{MHz})$ spectral analysis of compounds $325-3$ and $325-5$

\begin{tabular}{|c|c|c|c|c|}
\hline & Compound 325-3 & & Compound 325-5 & \\
\hline $\begin{array}{c}\text { Position } \\
1\end{array}$ & $\delta_{\mathrm{H}}(J$ in $\mathrm{Hz})$ & $\begin{array}{c}\delta_{c} \\
162.33\end{array}$ & $\delta_{\mathrm{H}}(\mathrm{J}$ in $\mathrm{Hz})$ & $\begin{array}{c}\delta_{\mathrm{c}} \\
161.95\end{array}$ \\
\hline 2 & $6.24(\mathrm{~d}, J=9.7 \mathrm{~Hz}, 1 \mathrm{H})$ & 125.12 & $6.25(\mathrm{~d}, J=9.7 \mathrm{~Hz}, 1 \mathrm{H})$ & 124.12 \\
\hline 3 & $7.00(\mathrm{dd}, J=9.7,5.5 \mathrm{~Hz}, 1 \mathrm{H})$ & 140.89 & $7.10(\mathrm{dd}, J=9.7,5.9 \mathrm{~Hz}, 1 \mathrm{H})$ & 141.00 \\
\hline 4 & $5.38(\mathrm{dd}, J=5.5,3.0 \mathrm{~Hz}, 1 \mathrm{H})$ & 63.41 & $5.66(\mathrm{dd}, J=5.8,2.8 \mathrm{~Hz}, 1 \mathrm{H})$ & 63.20 \\
\hline 5 & $5.10(\mathrm{~s}, 1 \mathrm{H})$ & 78.50 & $5.98(\mathrm{dd}, J=4.7,2.8 \mathrm{~Hz}, 1 \mathrm{H})$ & 76.85 \\
\hline 6 & $5.89(\mathrm{dd}, J=16.0,5.8 \mathrm{~Hz}, 1 \mathrm{H})$ & 124.73 & $\mathrm{H}-6 / \mathrm{H}-7: 6.42(\mathrm{~d}, J=4.7 \mathrm{~Hz}, 2 \mathrm{H}) *$ & 142.97 \\
\hline 7 & $6.01(\mathrm{dd}, J=15.5,5.2 \mathrm{~Hz}, 1 \mathrm{H})$ & 134.72 & $\mathrm{H}-6 / \mathrm{H}-7: 6.42(\mathrm{~d}, J=4.7 \mathrm{~Hz}, 2 \mathrm{H}) *$ & 124.54 \\
\hline 8 & $3.93(\mathrm{~s}, 1 \mathrm{H})$ & 76.22 & & 202.04 \\
\hline 9 & $3.62(\mathrm{~s}, 1 \mathrm{H})$ & 70.60 & $4.36(\mathrm{q}, J=7.1 \mathrm{~Hz}, 1 \mathrm{H})$ & 73.14 \\
\hline 10 & $1.17(\mathrm{~d}, J=6.3 \mathrm{~Hz}, 3 \mathrm{H})$ & 11.98 & $1.40(\mathrm{~d}, J=7.1 \mathrm{~Hz}, 3 \mathrm{H})$ & 19.59 \\
\hline $1^{\prime}$ & $6.90(\mathrm{~d}, J=6.0 \mathrm{~Hz}, 1 \mathrm{H})$ & 140.89 & $6.86(\mathrm{dd}, J=7.3,1.7 \mathrm{~Hz}, 1 \mathrm{H})$ & 139.57 \\
\hline $2^{\prime}$ & & 127.60 & & 127.53 \\
\hline $3^{\prime}$ & $1.80(\mathrm{~s}, 3 \mathrm{H})^{\star}$ & 18.84 & $1.79(\mathrm{~s}, 3 \mathrm{H})^{*}$ & 14.54 \\
\hline $1 ”$ & & 166.74 & & 166.50 \\
\hline $2 ”$ & $1.81(\mathrm{~s}, 3 \mathrm{H})^{\star}$ & 14.54 & $1.80(\mathrm{~s}, 3 \mathrm{H})^{\star}$ & 12.00 \\
\hline $\mathrm{OH}$ & C-8/C-9: $2.22(\mathrm{bs}, 1 \mathrm{H}) ; 2.16(\mathrm{bs}, 1 \mathrm{H})$ & & C-9: $3.36(\mathrm{bs}, 1 \mathrm{H})$ & \\
\hline
\end{tabular}



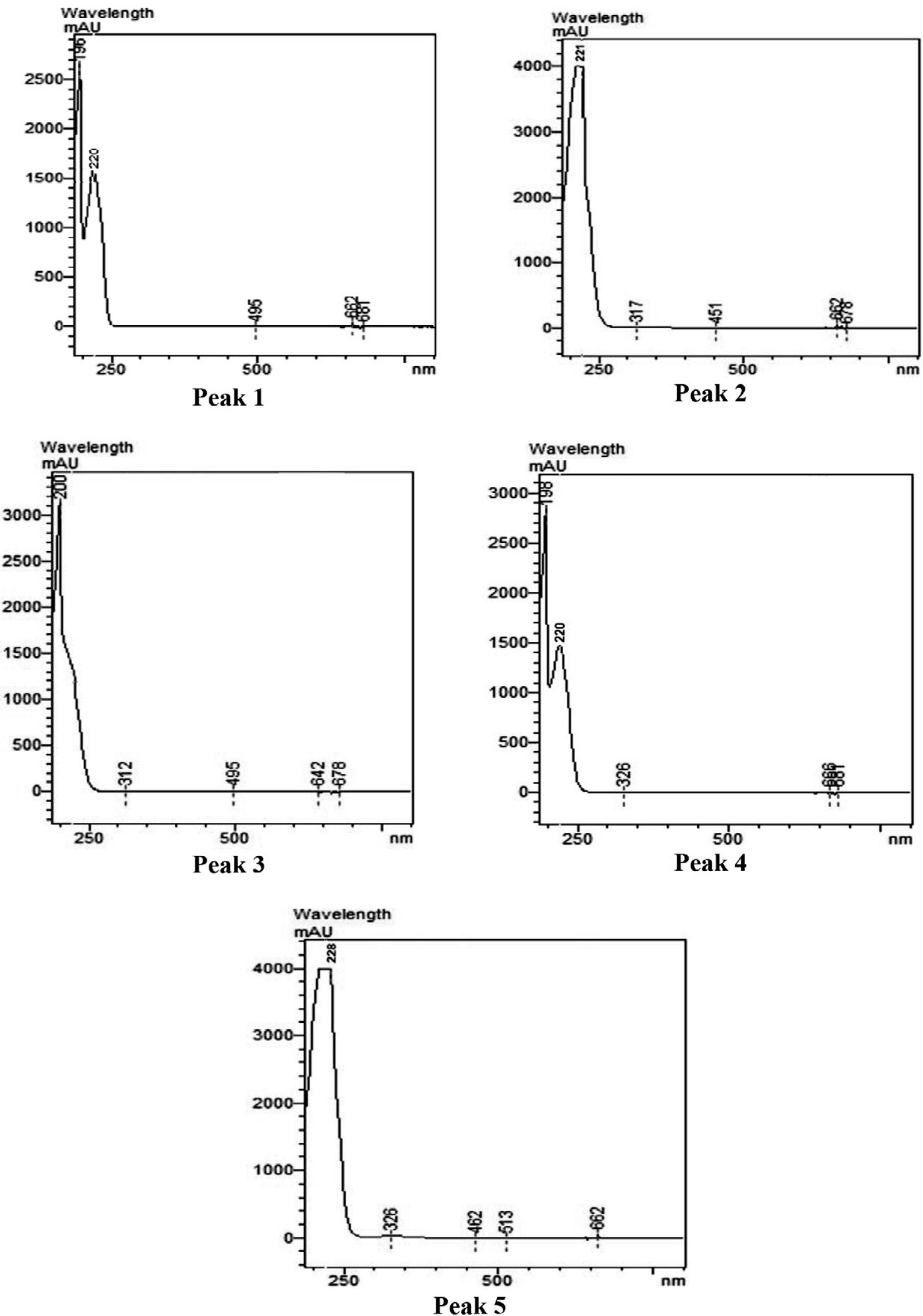

Figure 2. Absorption spectra of compounds corresponding to five peaks chromatographed using dichloromethane dry extract dissolved in methanol and water 50:50 (v/v) 
A Abundance

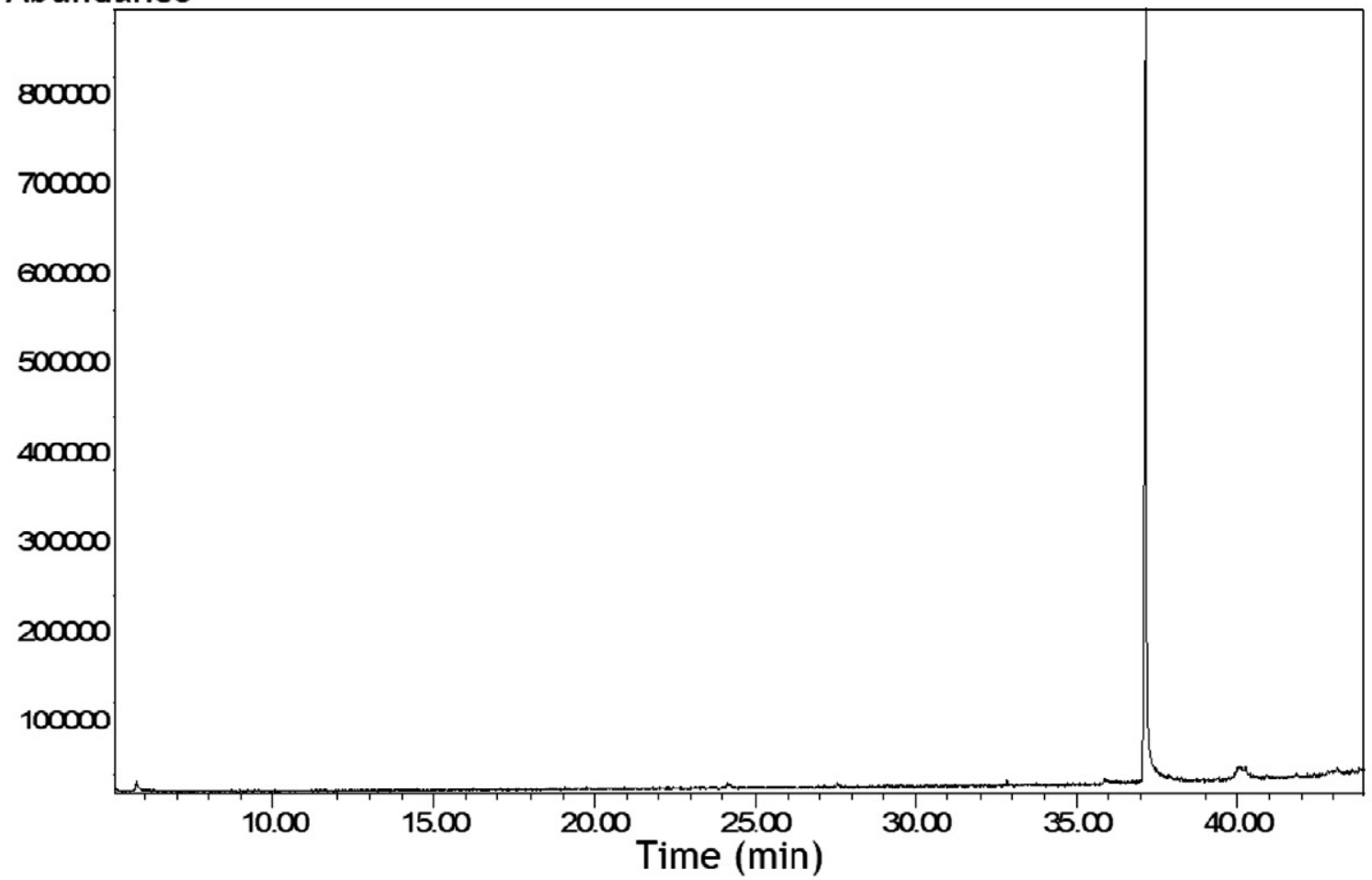

B

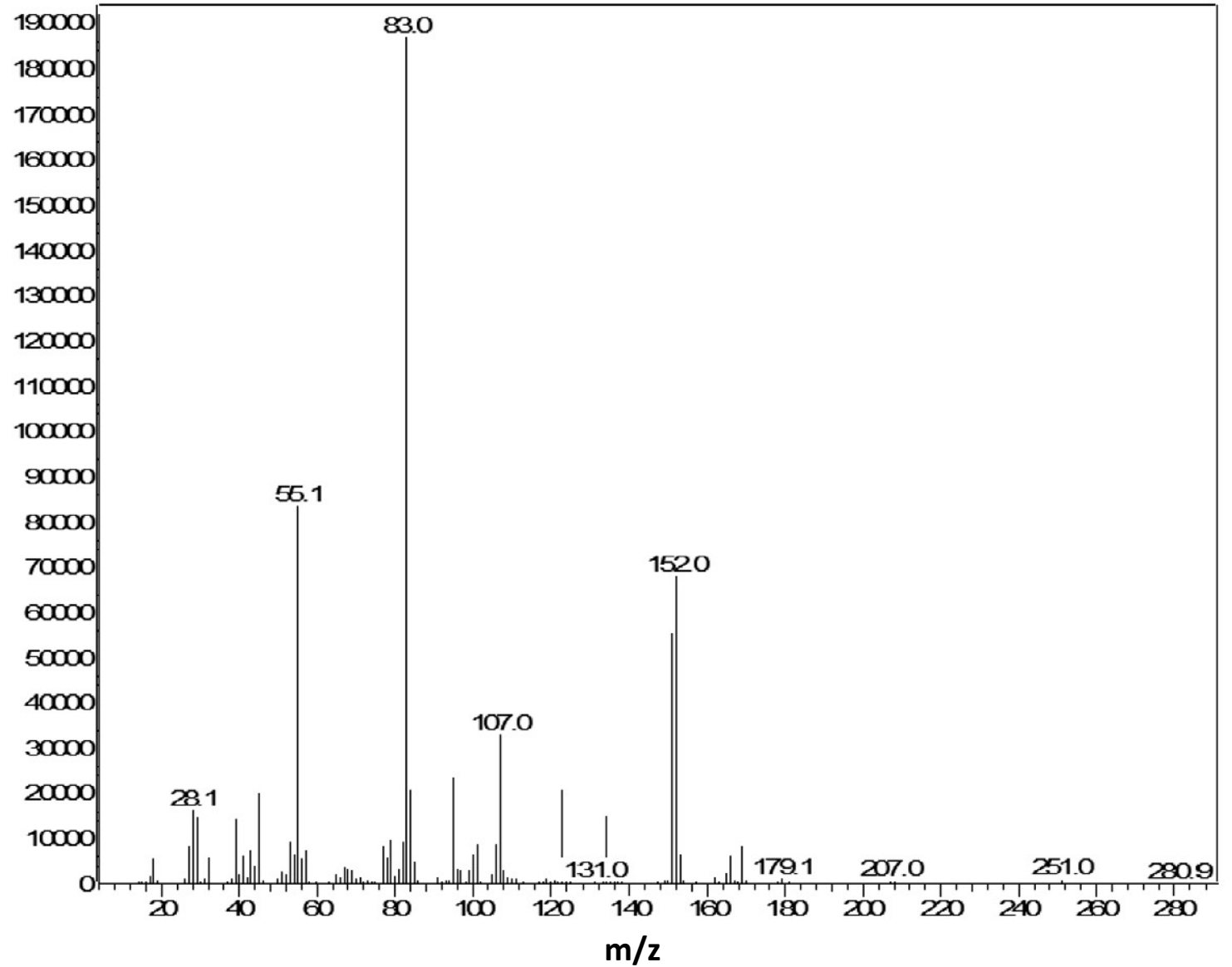

Figure 3. Total ion chromatogram (A) and GC/MS spectra (B) of compound 325-3 

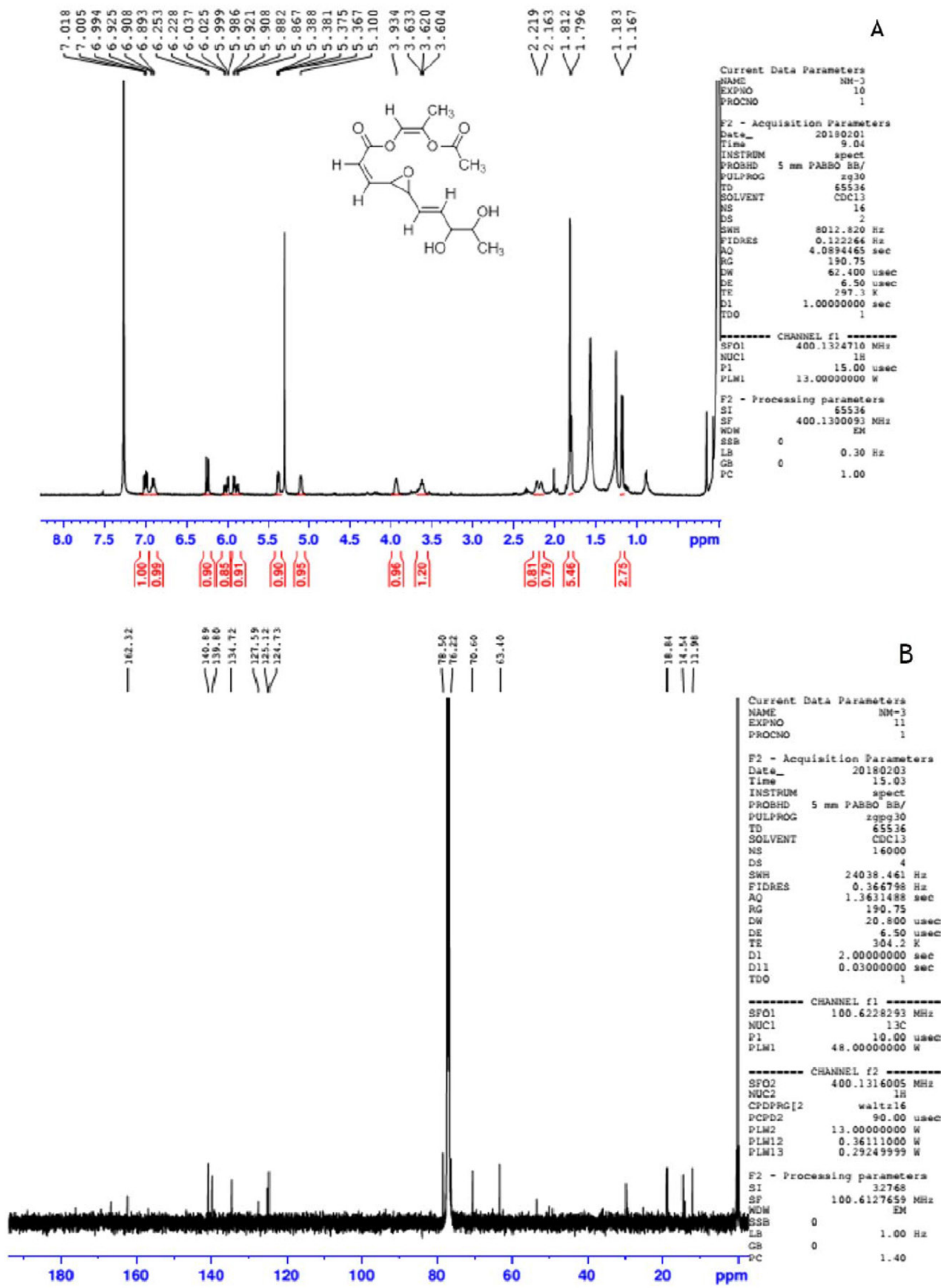

Figure 4. ${ }^{1} \mathrm{H}$ NMR spectra (A), ${ }^{13} \mathrm{C}$ NMR spectra (B) for toluene standard and compound 325-3 


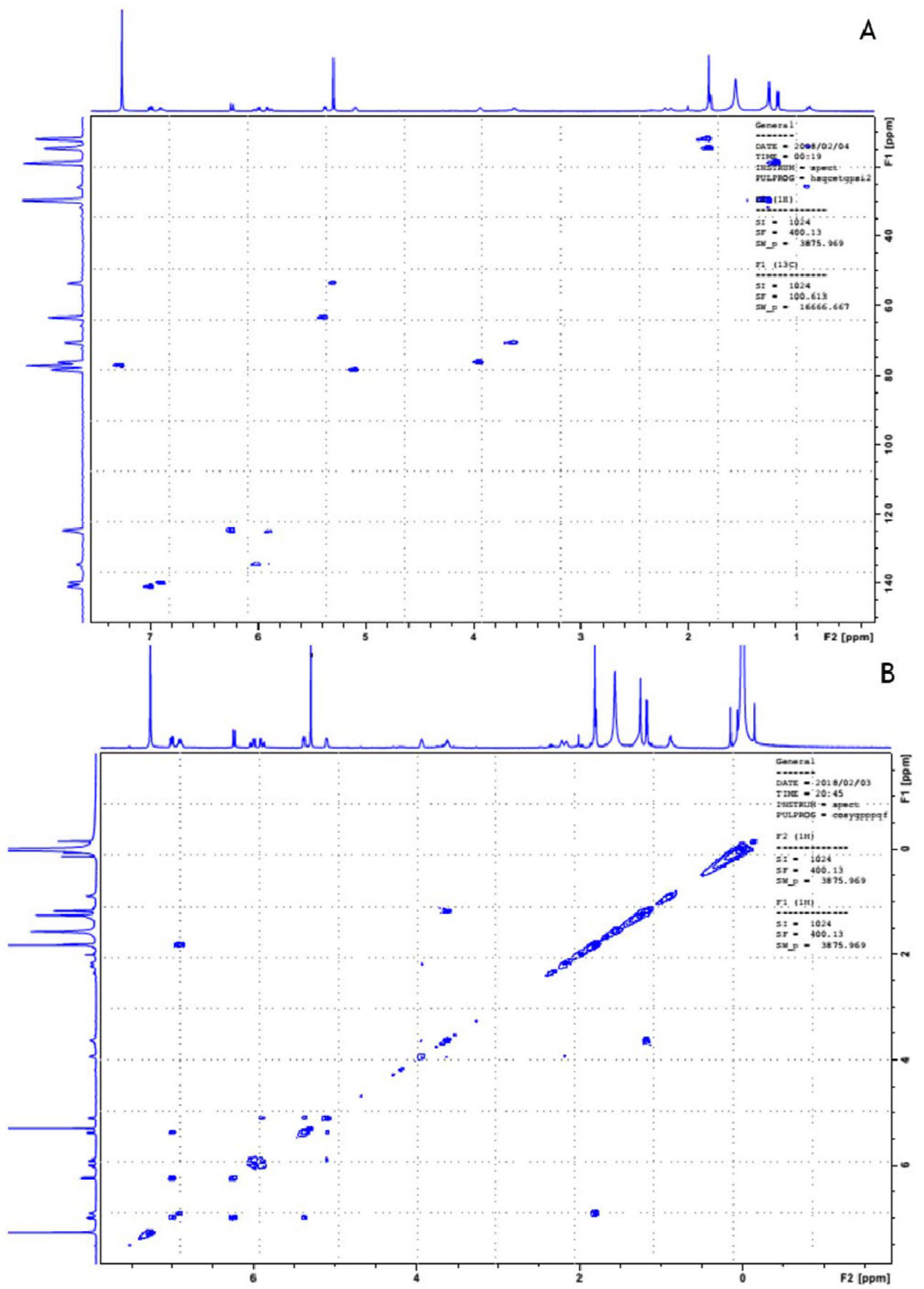

Figure 5. HSQC (A) and COSY (B) spectra of compound 325-3 

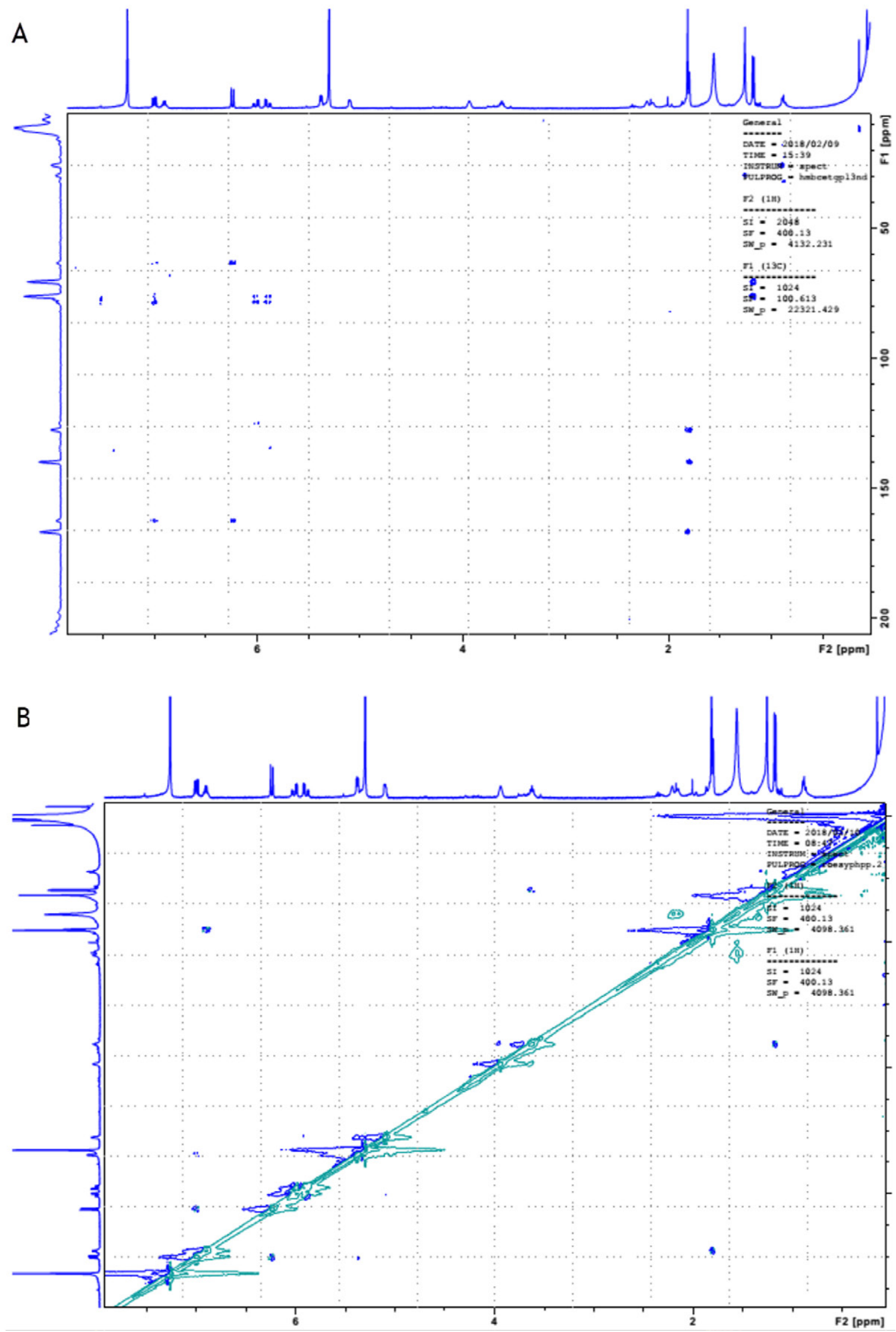

Figure 6. HMBC (A) and NOESY (B) spectra of compound 325-3 
A

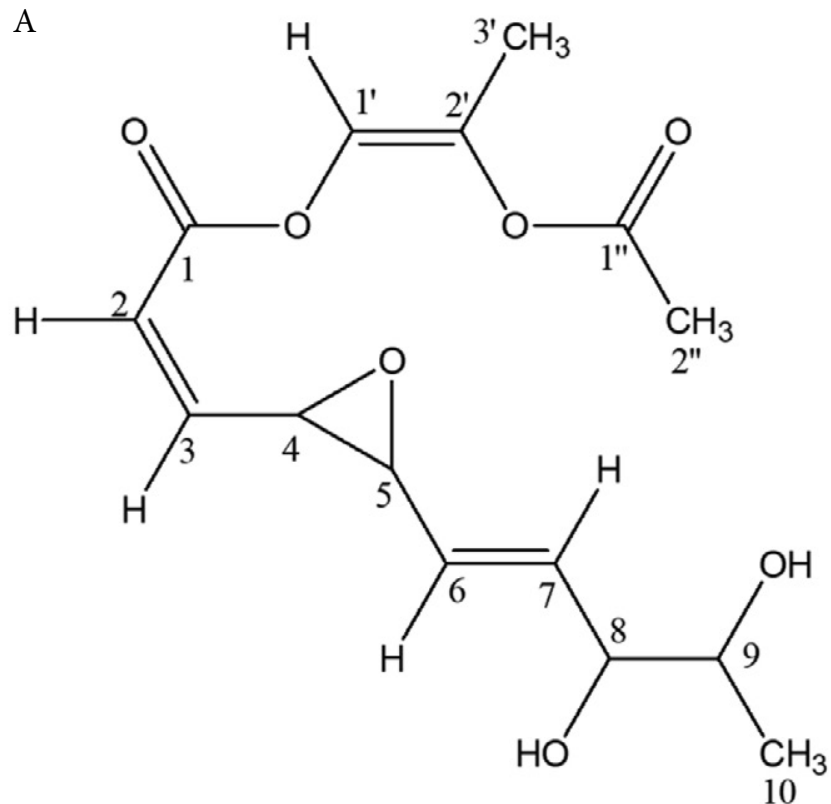

B

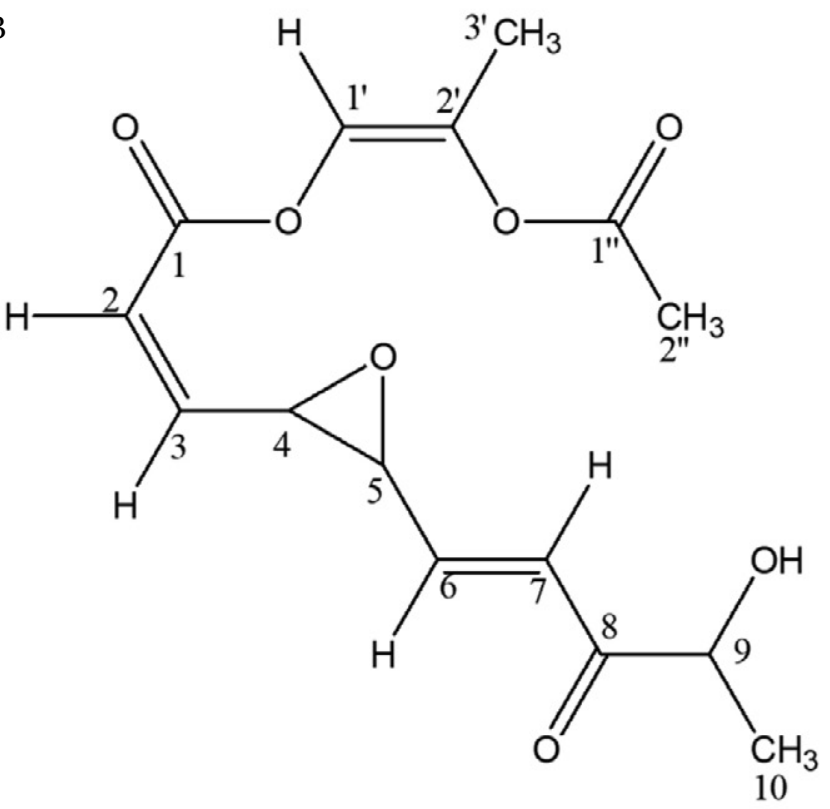

Figure 7. Molecular structures of compounds 325-3 (A) and 325-5 (B)

and 5 showed bioactivity. Therefore, after fraction collection and weighing of evaporated fractions, it has been noticed that dry mass of the collected peak fractions 3 and 5 was at least $5 \mathrm{mg}$, which was dissolved with deuterochloroform in cuvette up to volume of $250 \mu \mathrm{L}$. The final concentration was high enough to perform suitable NMR analysis. The compounds corresponding to peak 3 and 5 were denoted as 325-3 and 325-5 in further text, respectively.

Compound that corresponded to peak 3 in the chromatogram and denoted as 325-3, was obtained as a colourless oil with the molecular formula of $\mathrm{C}_{15} \mathrm{H}_{20} \mathrm{O}_{7}$ (recorded by GC-MS method as ion $\left[\mathrm{M}+\mathrm{H}-\mathrm{OH}-\mathrm{CH}_{3}\right]=281$, calc. 313.1282, Figure 3). The numbers of hydrogen and carbon atoms observed in the ${ }^{1} \mathrm{H}$ - and ${ }^{13} \mathrm{C}-\mathrm{NMR}$ spectra recorded in $\mathrm{CDCl}_{3}$ (Table 1) were in agreement with the molecular formula. The ${ }^{1} \mathrm{H}$ NMR (Figure 4A) data indicated the existence of five $\mathrm{sp}^{2}$ methines (H-2, H-3, H-6, H-7 and H-1'), four oxygenated $\mathrm{sp}^{3}$ methines $(\mathrm{H}-4, \mathrm{H}-5, \mathrm{H}-8$ and $\mathrm{H}-9)$, two hydroxyl and three methyl groups $(\mathrm{H}-10, \mathrm{H}-3$ ' and $\mathrm{H}-2$ "). The ${ }^{13} \mathrm{C}$ NMR (Figure $4 \mathrm{~B}$ ) and HSQC spectra (Figure $5 \mathrm{~A}$ ) indicated 15 carbons, which were classified into six olefinic carbons (C-2, C-3, C-6, C-7, C-1' and C-2'), four oxygenated $\mathrm{sp}^{3}$ methine carbons $(\mathrm{C}-4, \mathrm{C}-5, \mathrm{C}-8$ and C-9), three $\mathrm{sp}^{3}$ methyl carbons (C-10, C-3' and C-2") and two carbonyl carbons (C-1 and C-1"). The ${ }^{1} \mathrm{H}-{ }^{1} \mathrm{H}$ COSY of compound 325-3 (Figure 5B) showed all expected bonds between hydrogens on adjacent carbons from $\mathrm{H}-2$ to $\mathrm{H}-10$ and from $\mathrm{H}-1$ ' to $\mathrm{H}-3$ '. The $\mathrm{HMBC}$ correlations (Figure 6A) from $\mathrm{H}-2$ to $\mathrm{C}-1, \mathrm{H}-3$ ' to $\mathrm{C}-2$ ' and $\mathrm{H}-2$ "' to C-2' also proved suggested structure. The $\mathrm{Z}$ geometries of C-1'/C-2' and C-2/C-3 double bonds were elucidated by the NOESY cross-peaks between $\mathrm{H}-2$ and $\mathrm{H}-3$ and $\mathrm{H}-1^{\prime}$ and $\mathrm{H}-3^{\prime}$ (Fig- ure $6 \mathrm{~B})$. Also, the absence of the NOESY cross-peak between H-6 and H-7 indicated $\mathrm{E}$ configuration of the C-6/C-7 double bond. Additionally, configurations of all double bonds were confirmed by magnitudes of the coupling constants in ${ }^{1} \mathrm{H}$-NMR spectra. Thus, the structure of compound 325-3 was finally elucidated as (Z)-(Z)-2-acetoxyprop-1-en-1-yl-3-(3-((E)-3,4-dihydroxypent-1-en-1yl)oxiran-2-yl)acrylate (Figure 7A). Geometric isomers of this compound were not detected.

Compound 325-5 was also obtained as a colourless oil, whose molecular formula was determined as $\mathrm{C}_{15} \mathrm{H}_{18} \mathrm{O}_{7}$ (recorded by GC-MS method as ion $[\mathrm{M}+\mathrm{H}-\mathrm{OH}-\mathrm{CH} 3]=$ 279, calc. 311.1125, Figure 8). A comparison of ${ }^{1} \mathrm{H}$ spectra (Figure 9A) showed that compound 325-5 shared the same spectroscopic characteristics with compound 325-3, with one oxygenated $\mathrm{sp}^{3}$ methine and one hydroxyl group less. In the ${ }^{13} \mathrm{C}$ NMR spectra of compound 325-5 (Figure 9B), three carbonyl carbon signals and three oxygenated $\mathrm{sp}^{3}$ methines were detected, suggesting that compound 325-5 was oxidation product of compound $325-3$. The ${ }^{1} \mathrm{H}-{ }^{1} \mathrm{H}$ COSY (Figure 10B) showed bonds between hydrogens on adjacent carbons from $\mathrm{H}-2$ to $\mathrm{H}-7$ and from $\mathrm{H}-9$ to $\mathrm{H}-10$ indicated carbonyl group at $\mathrm{C}-8$. The HMBC correlations (Figure 11A) from $\mathrm{H}-7$ to additional carbonyl group also supported this assumption. Configurations of all double bonds were found to be the same as of compound 325-3, based on the analysis of NOESY spectrum (Figure 11B) and magnitudes of the coupling constants. Based on this, the structure of compound 325-5 was determined as $(\mathrm{Z})$ (Z)-2-acetoxyprop-1-en-1-yl 3-(3-((E)-4-hydroxy-3-oxopent-1-en-1-yl)oxiran-2-yl)acrylate (Figure 7B). Geometric isomers of this compound were not detected. 


\section{A Abundance}

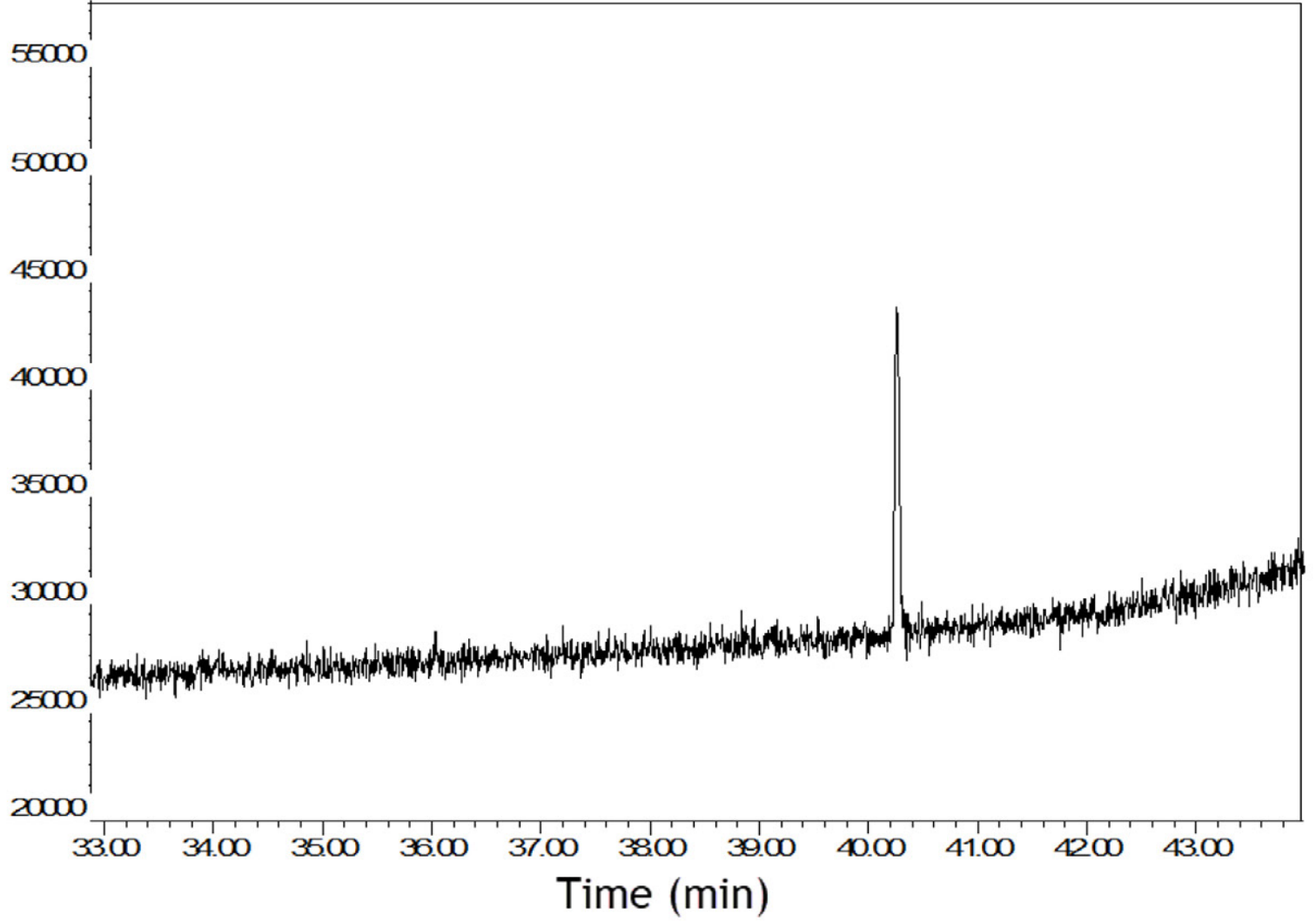

B

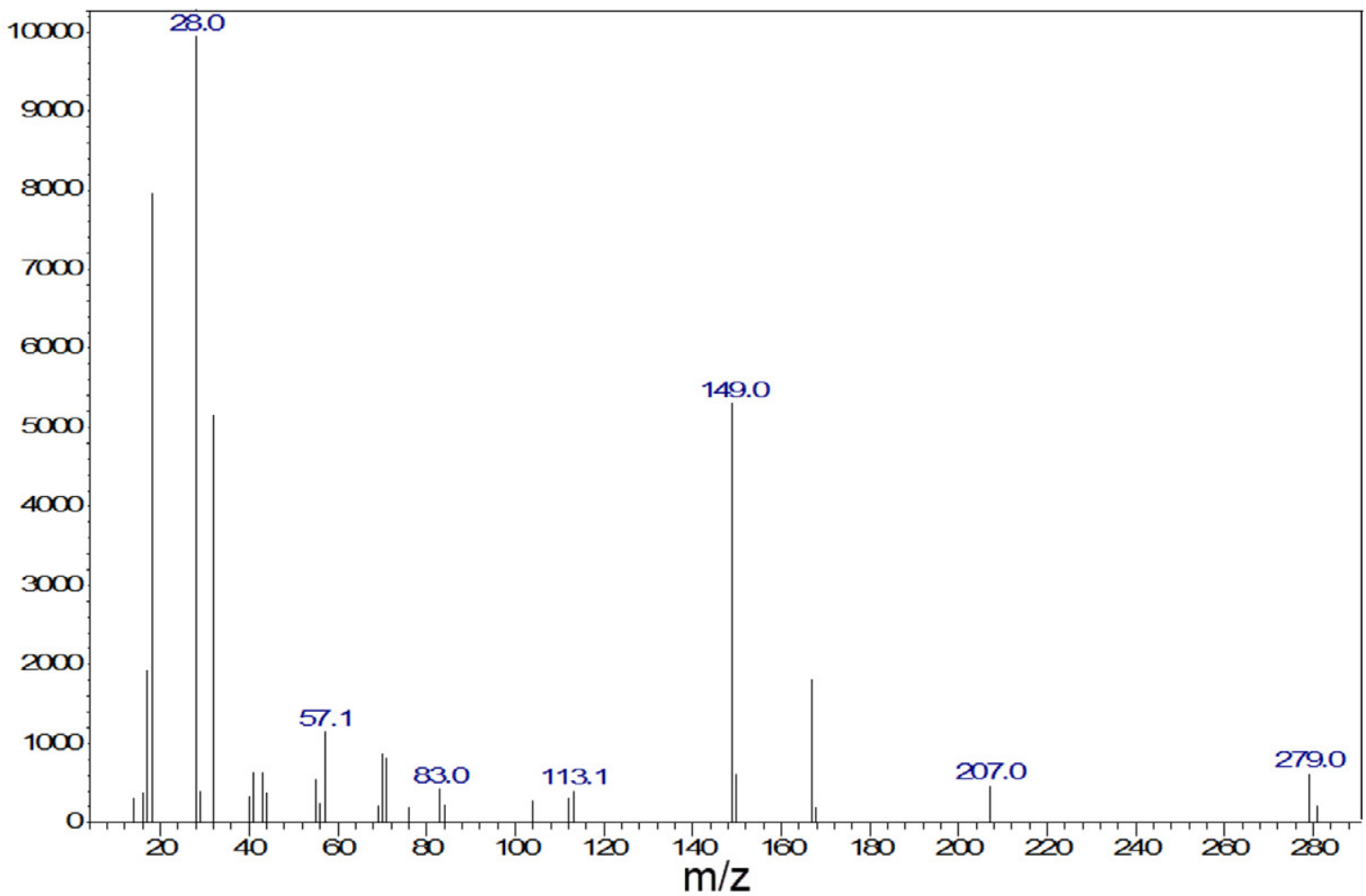

Figure 8. Total ion chromatogram (A) and GC/MS spectra (B) of compound 325-5 


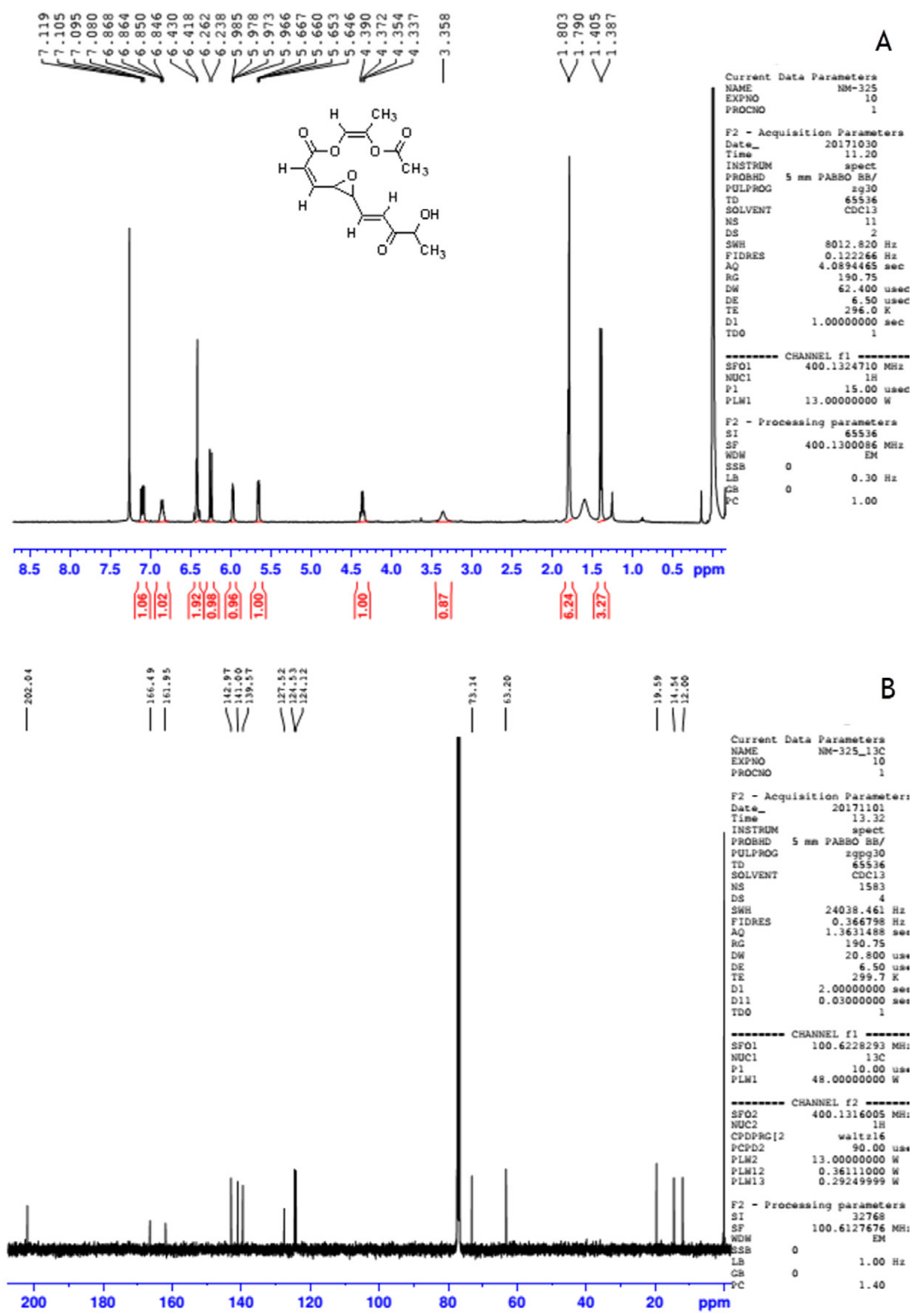

Figure 9. ${ }^{1} \mathrm{H}$ NMR spectra (A), ${ }^{13} \mathrm{C}$ NMR spectra (B) for toluene standard and compound 325-5 

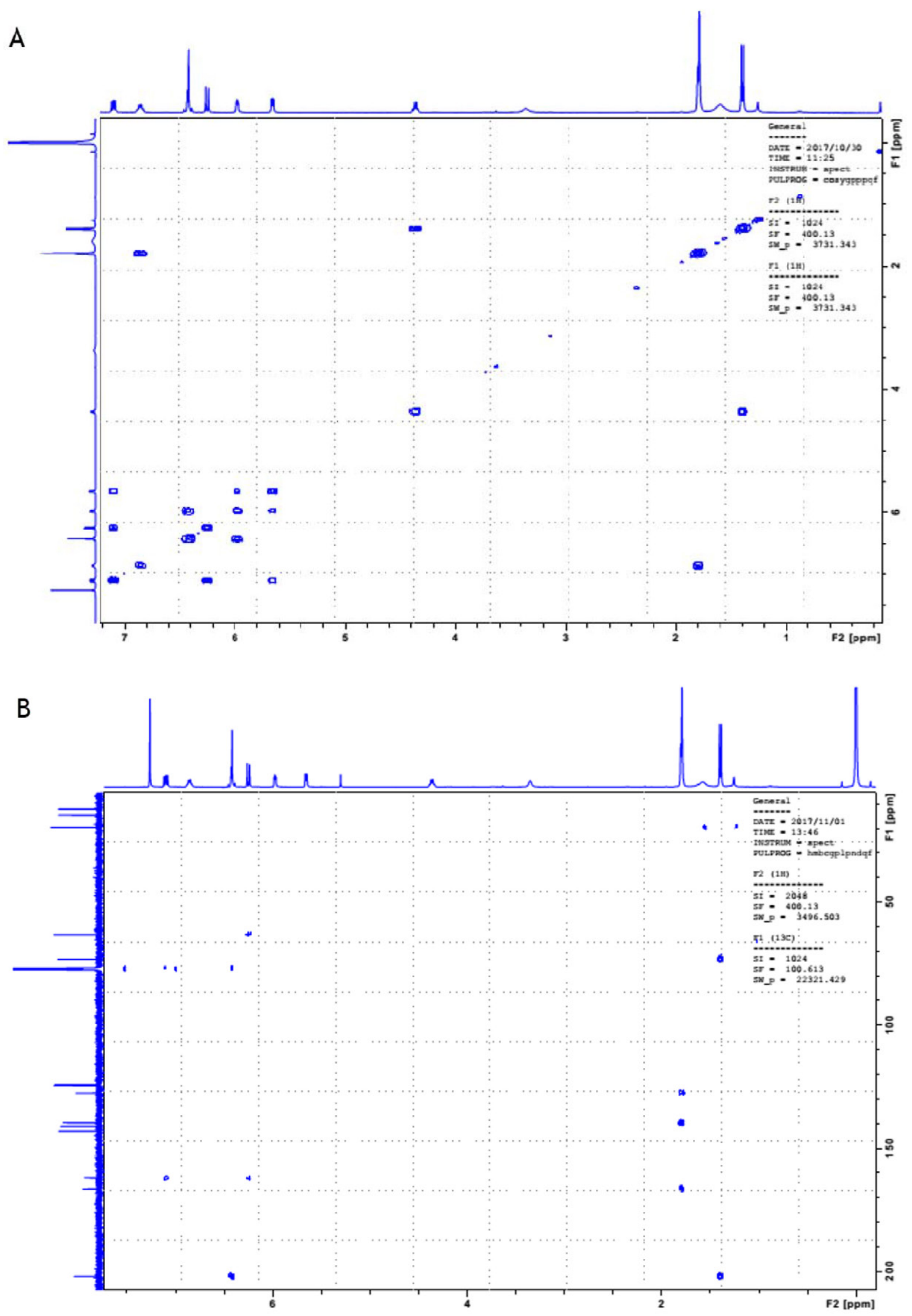

Figure 10. HSQC (A) and COSY (B) spectra of compound 325-5 

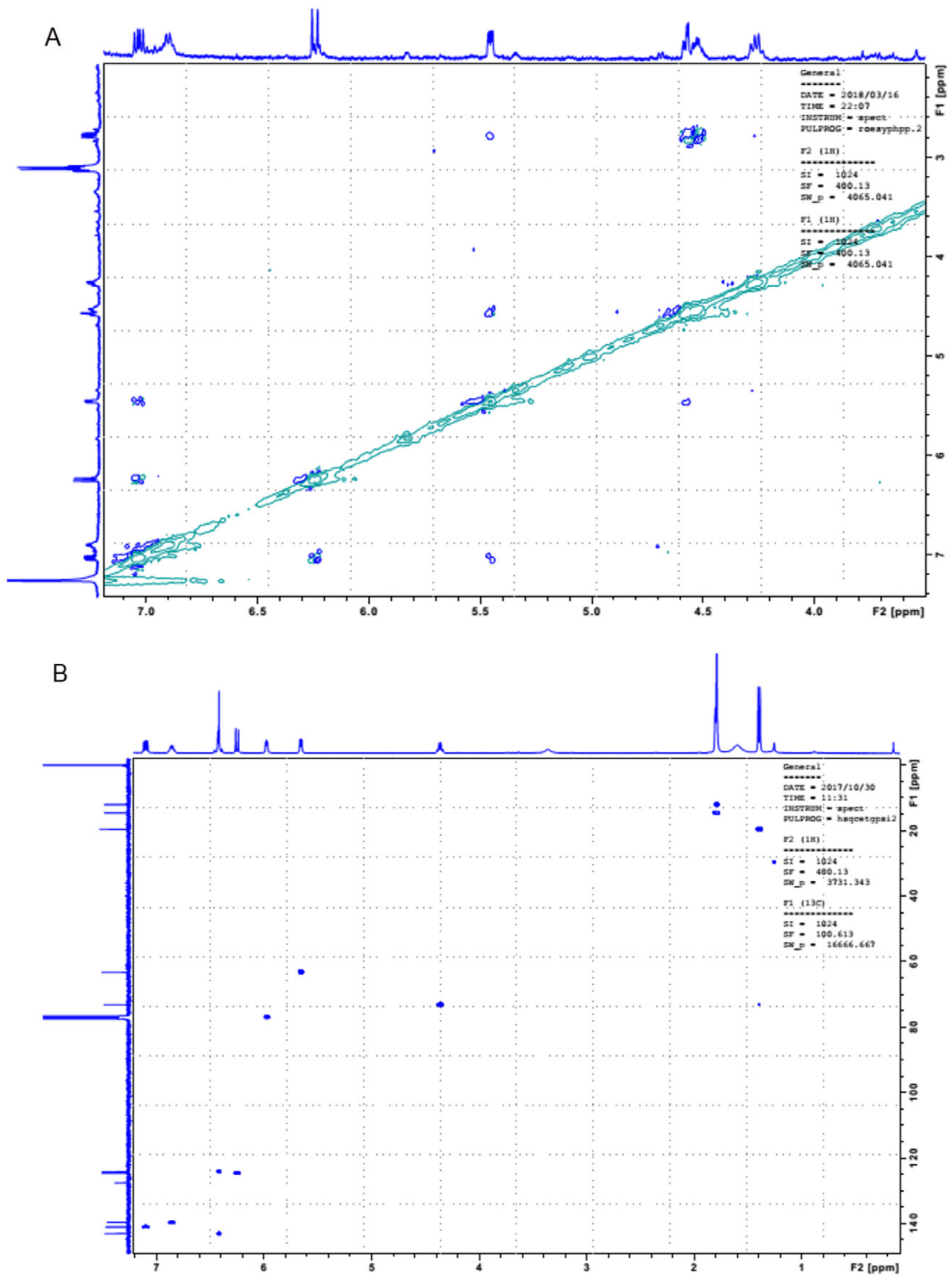

Figure 11. HMBC (A) and NOESY (B) spectra of compound 325-5 
Phomopsis sp. was already recognized as potent producer of bioactive compounds. However, it can be noticed that Phomopsis $s p$. is able to produce a variety of known secondary metabolites with great differences in chemical compositions. Among them, relatively small molecule which is similar to compounds resulted from our study, is phomoenamide, a metabolite of Phomopsis sp. PSU-D15 isolated from leaves of Garcinia dulcis (Roxb.) Kurz. that has moderate activity against $M$. tuberculosis. ${ }^{27}$ Another endophytic fungi, Culvularia geniculate obtained from limbs of $\mathrm{Ca}$ tunaregam tomentosa, produces five metabolites known as culvularides A-E, with similar structures to molecules from Phomopsis species we have characterized. For cuvularides A-E antifungal activity against Candida albicans has been determined. ${ }^{28}$ Therefore, the authors consider that the future perspective of this research could be directed towards spreading the antimicrobial assay evaluation in accordance with mentioned indices from literature records.

\section{Conclusions}

Within this scientific article, antibiotic potential of endophyte Phomopsis species isolated from conifer needles has been determined against bacteria Escherichia coli and Staphylococcus aureus. Dominant compounds potentially responsible for antimicrobial activity have been discussed. Based on their antimicrobial activity and unique structural characteristics in comparison with well-established drugs from the same therapeutic category, two dominant compounds (Z)-(Z)-2acetoxyprop-1-en-1-yl-3-(3-((E)-3,4-dihydroxypent-1-en-1yl)oxiran-2-yl)acrylate (denoted as 325-3) and (Z)-(Z)-2-acetoxyprop-1-en-1-yl 3-(3-((E)-4-hydroxy-3-oxopent-1-en1-yl)oxiran-2-yl)acrylate (denoted as 325-5) were characterized. Moreover, based on their specific properties, these biomolecules could serve as leading structures for further antibiotic drug discovery. The evaluation of relationship between the chemical structure and the intensity of antibacterial activity may provide guidelines for development of series of new derivatives and further improvement of bioactivity.

\section{Acknowledgements}

This scientific research has been funded by Ministry of Education, Science and Technological Development of Republic of Serbia (project no. 172033) and Slovenian Research Agency (grant number P4-0127) within bilateral projects between Faculty of Pharmacy, University in Belgrade, Serbia and Faculty of Pharmacy, University in Ljubljana, Slovenia, EU (project no. BI-RS/16-17-022).

\section{References}

1. M. Wink, Phytochemistry. 2003, 64, 3-19.

DOI:10.1016/S0031-9422(03)00300-5
2. H. Nisa, A. N. Kamili, I. A. Nawchoo, S. Shafi, N. Shameem, S. A. Bandh, Microb. Pathog. 2015, 82, 50-59.

DOI:10.1016/j.micpath.2015.04.001

3. B. Schulz, C. Boyle, S. Draeger, A. K. Römmert, K. Krohn, Mycol. Res. 2002, 106, 996-1004.

DOI:10.1017/S0953756202006342

4. S. Kusari, C. Hertweck, M. Spiteller, Chem. Biol. 2012, 19, 792-798. DOI:10.1016/j.chembiol.2012.06.004

5. D. Udayanga, X. Liu, E. H. McKenzie, E. Chukeatirote, A. H. Bahkali, K. D. Hyde, Fungal Diversity. 2011, 50, 189-225. DOI:10.1007/s13225-011-0126-9

6. A. E. Arnold, L. C. Mejía, D. Kyllo, E. I. Rojas, Z. Maynard, N. Robbins, E. A. Herre. Proc. Natl. Acad. Sci. 2003, 100, 1564915654. DOI:10.1073/pnas.2533483100

7. G. A. Strobel, Microbes. Infect. 2003, 5, 535-544. DOI:10.1016/S1286-4579(03)00073-X

8. R. P. Ryan, K. Germaine, A. Franks, D. J. Ryan, D. N. Dowling, FEMS Microbiol. Lett. 2008, 278, 1-9. DOI:10.1111/j.1574-6968.2007.00918.x

9. R. X. Tan, W. X. Zou, Nat. Prod. Rep. 2001, 18, 448-459. DOI:10.1039/b100918o

10. Z. Deng, L. Cao, Chemosphere. 2017, 168, 1100-1106. DOI:10.1016/j.chemosphere.2016.10.097

11. S. L. Doty, New Phytol. 2008, 179, 318-333. DOI:10.1111/j.1469-8137.2008.02446.x

12. H. Hussain, M. K. Tchimene, I. Ahmed, K. Meier, M. Steinert, S. Draeger, B. Schulz, K. Krohn, Nat. Prod. Commun. 2011, 6, 1905-1906. DOI:10.1177/1934578X1100601228

13. M. Corrado, K. F. Rodrigues, Int. J. Biochem. Physiol. Genet. Morphol. Ecol. Microorg. 2004, 44, 157-160.

DOI:10.1002/jobm.200310341

14. M. Isaka, A. Jaturapat, K. Rukseree, K. Danwisetkanjana, M. Tanticharoen, Y. Thebtaranonth, J. Nat. Prod. 2001, 64, 10151018. DOI:10.1021/np010006h

15. G. Jayanthi, S. Kamalraj, K. Karthikeyan, J. Muthumary, Int. J. Curr. Sci. 2011, 1, 85-90.

16. D. Rakshith, P. Santosh, S. Satish, Int. J. Chem. Anal. Sci. 2013, 4, 156-160. DOI:10.1016/j.ijcas.2013.08.006

17. V. Rukachaisirikul, U. Sommart, S. Phongpaichit, J. Sakayaroj, K. Kirtikara, Phytochem. 2008, 69, 783-787. DOI:10.1016/j.phytochem.2007.09.006

18. Z. Huang, X. Cai, C. Shao, Z. She, X. Xia, Y. Chen, J. Yang, S. Zhou, Y. Lin, Phytochem. 2008, 69, 1604-1608. DOI:10.1016/j.phytochem.2008.02.002

19. L. Mostert, P. W. Crous, J. C. Kang, A. J. Phillips, Mycol. 2001, 93, 146-167. DOI:10.1080/00275514.2001.12061286

20. E. L. Diogo, J. M. Santos, A. J. Phillips, Fungal Divers. 2010, 44, 107-115. DOI:10.1007/s13225-010-0057-x

21. D. F. Farr, L. A. Castlebury, A. Y. Rossman, Mycol. 2002, 94, 494-504. DOI:10.1080/15572536.2003.11833214

22. D. Rakshith, P. Santosh, S. Satish, Int. J. Chem. Anal. Sci. 2013, 4(3), 156-160.

DOI:10.1016/j.ijcas.2013.08.006

23. H. Hussain, M. K. Tchimene, I. Ahmed, K. Meier, M. Steinert, S. Draeger, B. Schulz, K.Krohn, Nat. Prod. Commun. 2011, 6(12), 1905-1906. DOI:10.1177/1934578X1100601228 
24. M. Ravnikar, M. Tercelj, D. Janeš, B. Štrukelj, S. Kreft, Afr. J. Biotechnol. 2015, 14, 867-871. DOI:10.5897/AJB2014.14387

25. M. Friedman, P. R. Henika, C. E. Levin, R. E. Mandrell, J. Agric. Food Chem. 2004, 52(19), 6042-6048.

DOI:10.1021/jf0495340

26. M. Godoy-Gallardo, C. Mas-Moruno, M. C. Fernández-Calderón, C. Pérez-Giraldo, J. M. Manero, F. Albericio, F., J. G. Francisco, D. Rodríguez, Acta Biomater. 2014, 10(8),
3522-3534. DOI:10.1016/j.actbio.2014.03.026

27. V. Rukachaisirikul, U. Sommart, S. Phongpaichit, J. Sakayaroj, K. Kirtikara, Phytochem. 2008, 69(3), 783-787.

DOI:10.1016/j.phytochem.2007.09.006

28. P. Chomcheon, S. Wiyakrutta, T. Aree, N. Sriubolmas, N. Ngamrojanavanich, C. Mahidol, S. Ruchirawat, P. Kittakoop, Chem. - Eur. J. 2010, 16(36), 11178-11185.

DOI:10.1002/chem.201000652

\section{Povzetek}

V zadnjem desetletju je vse več zanimanja namenjenega raziskovanju bioaktivnih sekundarnih metabolitov endofitnih gliv. Kot nadaljevanje naših predhodnih raziskav na področju endofitnih gljiv s protimikrobnim potencialom, smo izbrali in izolirali vrsto Phomopsis sp. iz iglic iglavcev. Diklorometanski in etanolni ekstrakt Phomopsis sp. sta znatno zavirala rast bakterij Escherichia coli in Staphylococcus aureus. Spojine diklorometanskega izvlečka so bile ločene, zbrane in očiščene s pomočjo tehnike semi-preparativne visoko zmogljivostne tekočinske kromatografije (HPLC) ter okarakterizirane s tehnikama masne spektrometrije (MS) in jedrske magnetne resonančne spektroskopije (NMR). Na podlagi protimikrobne aktivnosti in edinstvenih strukturnih značilnosti, v primerjavi z uveljavljenimi zdravilnimi učinkovinami iz iste terapevtske kategorije, sta bili dve prevladujoči spojini (Z)-(Z) -2-acetoksiprop-1-en-1-il-3- (3- ((E) -3,4-dihidroksipent-1-en-1-il)oksiran-2-il)akrilat (označen kot 325-3) in (Z)-(Z)-2-acetoksiprop-1-en-1-il-3-(3-((E)-4-hidroksi3-oksopent-1-en-1-il)oksiran-2-il)akrilat (označen kot 325-5) prepoznani kot obetavni spojini za nadaljnje raziskave na področju novih naravnih antibiotičnih učinkovin.

Except when otherwise noted, articles in this journal are published under the terms and conditions of the Creative Commons Attribution 4.0 International License 